\title{
The strategy for planning the future of a Christian believer in the exegetical context of James 4:13-15
}

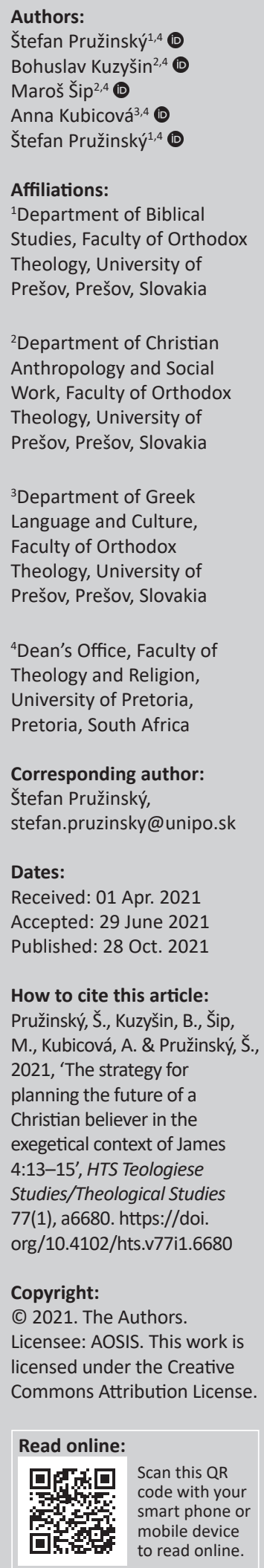

This article deals primarily with the examination of two key and exegetically demanding expressions in the text of the General Epistle of James, which relate to fundamental biblical principles on planning the future of the believer and reconciling human life with God's will expressed in Holy Scripture. The first one is the hapax legomenon 'A $\gamma \varepsilon v \tilde{v} v$, the significance of which is closely related to updating of the affected principles with practice. The second term is $\pi$ oiń $\sigma 0 \mu \varepsilon v$, which, in most translations, translates as 'remain' and does not reflect the core idea of the examined verse. We prove that a more authentic and appropriate translation is 'work'. Our aim was to find out what new interpretive possibilities the original biblical text offers. The constitutive starting point for research is Novum Testamentum Graecum - Editio Critica Maior. We then compared these texts with the Slovak Ecumenical Bible. The method of our exegetical work was not primarily comparison, but a linguistic analysis and historical-critical exegesis, the result of which is a completely new proposal for the translation of the scrutinised texts. Auxiliary materials were the most important patristic and exegetical commentaries. In conclusion, we state that the analysis made it possible to find a new translation of the researched text, which can really contribute to the improvement of further review and publication of the ecumenical translation of the Bible into various languages.

Contribution: The article examines the source Greek biblical text of James 4:13-15 and reveals a new interpretation of it. This interpretation brings a new, biblical light into the field of planning, which is one of the most current topics nowadays. With its content and especially its conclusions, it contributes to the goals of this theological journal, the subject of which is also the research of Greek biblical manuscripts.

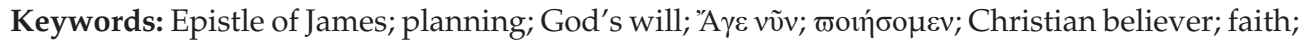
strategy; future.

\section{Introduction}

In the General Epistle of Saint Apostle James there are words expressing the sharp disagreement of the biblical author with the activities and plans of people for their future without consideration for God's will (1). We have in mind the following words:

Now listen, you who say, 'Today or tomorrow we will go to such and such a city, work a year there, buy and sell, and get gain'; whereas you do not even know what will happen tomorrow. For what is your life? It is even a vapour that appears for a little time and then vanishes away. Instead, you ought to say, 'If the Lord wills, we shall live and do this or that!' (Ja 4:13-15) ${ }^{1}$

Now, it is very important to explain the value of the study we will present to you on the following pages. As we know, future planning is a huge topic not only among theological scholars but also in the ranks of ordinary people, businessmen, politicians, environmentalists, teachers and all the people who perform any sort of activity. What is more, the strategy for planning has been developed in various spheres of society; we already use agile planning and a lot of different frameworks for proper planning, controlling, supervising and executing our projects (e.g. Scrum in IT field and others). However, in the field of theology in recent times we are missing such a clear method or framework, applicable to the period in which we live. Such a method can give our

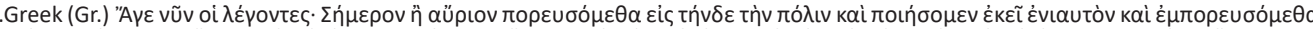

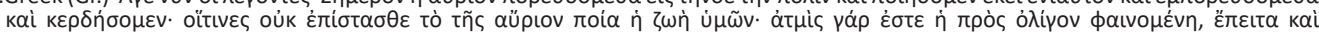

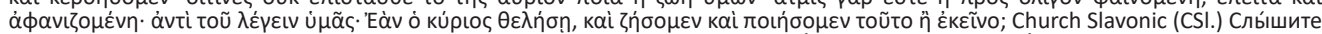
ны́lнь, глаго́лющіи: дне́сь или́ у́трь по́йдемъ во о́нъ гра́дъ, и сотвори́мъ ту́ лб́то еди́но, и ку́плю дб́емъ и приобрьте́ніе:и́же не вб́сте, что́ у́трь случи́тся: ка́я бо жи́знь ва́ша, па́ра бо е́сть, я́же вма́ль явля́ется, пото́мъ же исчеза́етъ. Вмб́сто е́же бы глаго́лати ва́мъ: а́ще Госпо́дь восхо́щетъ, и жи́ви бу́демъ, и сотвори́мъ сіе́ или́ о́но (Bibliıa 1993:1476).

Note: Special Collection: Faith Seeking Understanding, sub-edited by Seyed Mehdi Mousavi (Payame Noor University, Tehran, Iran) and the Dean's Office of the Faculty of Theology and Religion of the University of Pretoria. 
Christian society a vivid concept for planning or not planning our life, work, time or even future.

One of the most important pillars for this topic is a passage from the Epistle of James mentioned above, which, among others, contains two very special expressions ('A $\gamma \varepsilon$ võv, $\pi$ oí $\sigma o \mu \varepsilon v)$ that we are going to analyse, translate and interpret - in a unique way that brings to the researched topic even more light and perspective than before.

To sum up, our aim is to introduce to the scientific community the way, the system and the correct view on how to plan in accordance with the Holy Scriptures, explaining it from a new, modern perspective.

\section{The historical and social context of the studied biblical text}

We learn from James' letter that from among those addressees of the epistle who were most imbued with the secular spirit, James separates and addresses in the quoted verses those who were focussed on money and profit. Those people were specifically merchants. The apostle reproaches them for their absolute self-confidence and trust in themselves, which are the result of the high level of worldliness, the orientation towards purely material values and the obliteration of God. Although these people most probably claimed to be Christians, as the letter is addressed primarily to the Jewish Christians and also, at large, to the Christians of all nations who became members of the New Testament Church - the New Israel (Cap 2019:228-229), they were at the same time people who were not capable of dissociating with the non-Christian way of life and thinking. According to St. Nicodemus the Hagiorite, they were people relying only on their own knowledge and will and ignored God's 'providence, cooperation and help' (Nikodémou 1986:141). The aim of apostle James is to confirm and encourage in faith the Christians thinking and acting in the proper way, by 'illustratively pointing out the questionable and unreasonable attitudes' (Agourídē 1956:76) of those who behaved neither in a Christian way nor in the spirit of Torah, which also demands good deeds, nor in the spirit of Gospel which demands faith in Jesus Christ or were even enemies of the Christians, whom they oppressed and exploited to achieve their own benefits and profit (cf. Ja 1:9-11; 2:6; 5:4-6). James tries to teach the addressees of the letter to understand the Torah in the way in which God has always intended it to be (Dt 8:17-18).

We can learn from the content of the above quoted verses that among Christians were, already from the early days of the Church, people from various social (Hanobik 2020:83) strata. Already from James 2:14-17, where James calls the believers to manifest their faith by providing clothes and food to other people, one can see that at least some of the believers of the early Church were so wealthy that they had enough means not only to provide a livelihood for their families, but at the same time to help other people in need, too. The above mentioned indicate that the recipients of James's letter came from various social strata' (Hanobik \& Jurašek 2019:158). There were poor whom the author of the letter assures the extraordinary support of God ... and there were also wealthier people dedicated to business ...

The fact that Christianity caught on in all social strata is also confirmed by Pliny's comment in one letter to the emperor Trajan from the beginning of the 2nd century (it relates to the region of Pontus, the present Northern Turkey), in which Pliny (2) refers to the fact that 'the Christians are represented in all age groups' (Hoppe 2001:88-89) and 'in all (social) strata' (Hangoni 2016:160-163).

\section{The exegetic analysis of the most important terms}

Words 'Listen now' (Gr. 'A $\gamma \varepsilon$ vṽv; Church Slavonic (CSI.) Сль́шите ны́нъ) are an imperative call for the immediate intensified attention of all those who are exaggeratedly selfassured in their plans for the future. The accent on 'now' points to the eschatological thinking of the apostle James who, just like apostle John (see Jn 1 2:18) and all the other biblical authors, emphasises the necessity to be, permanently and in every moment, vigilant and prepared for the second coming of Jesus Christ, which can be experienced, to a certain extent, even now. The term 'A $\gamma \varepsilon$ võv (Aland et al. 2014:76; Aland et al. 2018:693) can be found in the Holy Scripture only in James, in this place and also in the beginning of the fifth chapter (see Ja 5:1). The word 'A $\gamma \varepsilon$ 'combines with the plural and it is the mark of an elegant style' (Gryglewicz 1959:119). This is the imperative form of the verb ó $\gamma \omega$; its basic meaning is: to step, to walk, to go, to lead, to guide, to drive, to conduct, to bring, to take with, to attract (Dvoretskiĩ 1958:28-29; compare with Ráptē 1993:16-17). More literally, we could translate this call as: 'Come (and listen) now you, who speak'. However, as this is a letter and not an oral sermon performed in personal contact with the listeners, it is more adequate and understandable to rather use the word 'listen' in the translation. After all, this is indirect and inter-mediated contact with the listeners who are not asked to go somewhere. Finally, also the words 'you, who say' (Gr. oi $\lambda \dot{\varepsilon} \gamma o v \tau \varepsilon \varsigma ;$ CSl. глаго́лющіи) are meant not completely literally and in an exact reading. They are intended to be an approximate and general example of the self-assured spirit and way people think, 'arrogantly' (Ivanov 1893:21) speak and unscrupulously act, who decide only by themselves without consideration for God's will.

In the rush for profit, the mentioned merchants proceeded 'like in their power was the time, the live and the achievement of the desired goals' (Iâroshevskii 1901:254). The words

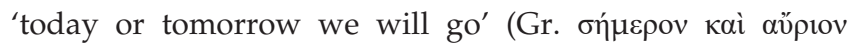
$\pi о \rho \varepsilon v \sigma o ́ \mu \varepsilon \theta \alpha$; CSl. дне́сь или́ у́трђ по́йдемъ) express the vain self-confidence about the time of their departure and the universal disposal of time. 


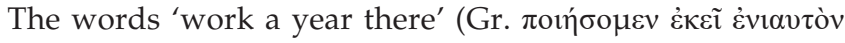

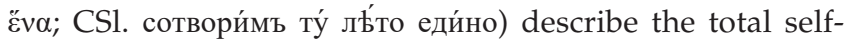
confidence regarding man's own life, work and health.

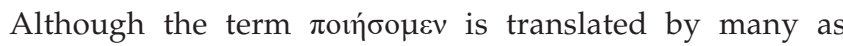
'remain' (stay) (3), from the results of the etymology of this word, it indicates that it is primarily a physical or intellectual activity. The basic meanings of this term are: to act, to do, to produce, to work, to make, to build, to give birth, to operate, to assemble, to compose, to create, to invent, to proceed. The translation of the word as a passive 'remain' (Bándy et al. 2015:262) does not change the meaning of this verse, and it does not express exactly its content either. In the I. Dvoreckýs Ancient Greek-Russian Dictionary, it is specified

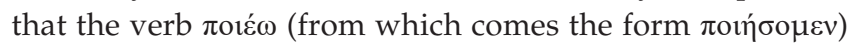
can be translated as 'to spend' or 'waste' time. However, this is an indirect and synonymous translation mentioned on the last but one, 21st place (Dvoretškir 1958:1335-1336). In the Great Dictionary of Verbs of the Greek author G. Rapti are presented only the active translations of this verb with the basic meaning of 'I strive for something to happen, I create something which has not existed so far' (Ráptē 1993:1104). The word ह่viaviòv in Greek points to 'a precisely defined time, most often a year' (Gryglewicz 1959:119; compare with Heb 9:7, 9; 10:1, 3).

And, at the end, in the words 'buy and sell, and get gain'

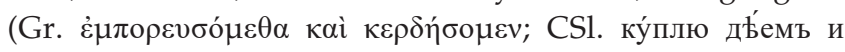
приобрьте́ніе) are expressed the self-confident certitude and conviction about the successful fulfilment of the goals and wishes set by them, too, without any mention of God and supplication for God's blessing and protection. The approach of those people is similar to an attitude of

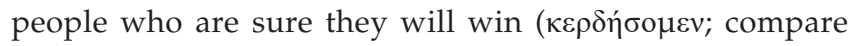
1 Cor 9:20). All their plans and efforts would be all right if they did not care only about worldly and material things but would be concerned that their work should be blessed (Cap 2018:207) by God; their life should be spiritually healthy and the gain adequate. All verbs used in this verse (we go, spend (time), buy, sell, get gain) as a whole create an impressive image of the self-important frame of mind of the merchants criticised by James, intensified as well by the fact that in the Greek language, these verbs form a rhyme. The senselessness of the confident plans for travel, work, business and profit without supplication for God's blessing and harmonisation with God's will is expressed also in the Gospel parable of the rich fool (see Lk 12:16-21). Like he did not live until the next morning, any traveller, worker or businessman may not live until the end and, in the worst case, until the beginning of his journey. And even if he would reach the planned destination of his travel, he may not be able to perform the planned work, and even if he performed it, he may not achieve the expected profit, and even if he would make a profit, he may not necessarily benefit in any way from it, not only because of the possible death in any of the phases of his plans, but also because of countless other obstacles and reasons which can stop, make impossible or devalue his plans.

\section{Biblical and non-biblical context of the studied text}

A criticism of the self-confident and unreasonable behaviour of the merchants who cannot know even what lies ahead of them the next night can be found also in the non-biblical authors. For example, in The Book of Enoch (97) it is written: 'Woe to you who acquire silver and gold, but not in righteousness', and say:

We have become very rich and have possessions, and have acquired everything that we desired. And now let us do what we planned, for we have gathered silver and filled our storehouses, and as many as water are the servants of our houses. And like water your life will flow away, for your riches will not stay with you, but will quickly go up from you, for you acquired everything in iniquity and you will be given over to a great curse. (pp. 8-10)

Similarly speaks also Seneca: 'But how foolish it is to set out one's life, when one is not even owner of the morrow!' (Seneca:228).

The orientation towards commerce of a continuously growing number of Jews - the majority of the addressees of the letter belonging to them - was not accidental. At its origin, an agricultural nation, after the Babylonian captivity (Ps 136 [137]), the Jewish nation gradually lost the understanding of and the love for its (original) occupation and started to see an ever-greater value in commerce. At the times of Jesus Christ, the poor Palestine was not able to feed all the Jews and more and more Jews departed to other foreign towns looking for some income. Most often, they were involved in trade. The members of the Jewish diaspora, dispersed throughout the whole Roman Empire (Ja 1:1), were in many cases very mobile and they remained for only a short time in one place, only where there was a chance for a larger income. An example of this mobility was the family of Aquila and Priscilla, who were in Rome, in Corinth and in Ephesus (Ac 18:1, 2, 26), then again in Rome ( $\mathrm{Rm} \mathrm{16:3),} \mathrm{then} \mathrm{once} \mathrm{more} \mathrm{in} \mathrm{Ephesus} \mathrm{(Tm} 2$ 4:19) and, besides these, they were most probably in other places as well, although there are not witnesses of that (Gryglewicz 1959:119-120).

James warns in this verse the addressees against 'the vanity manifested in the believe in ourselves and in the orientation towards materialism' (Kibal'chich' 2004:130). He warns them against the false conception that they are 'the absolute lords of their existence and independent from God' (Trempélas 1996:277). Such a condition is unnatural for man, as the resources and the possibilities of man are limited and very many things cannot be influenced or changed by man simply because he does not have this power. Man will always be dependent on God's help of which David the Psalmist tells: 'You hide Your face, they are troubled, You take away their breath, they die and return to their dust' (Ps 103 [104]:29). Man is not the lord of his future (Šak, Kochan \& Pilko 
2019b:18-19). His future depends in many ways on God's help, who willingly, with love and forbearance takes care of His entire creation (Mt 6:30; 10:29-30, Ps 146 [147]:8-9; 103 [104]:14-16; 144 [145]:15-16). Our dependence on God in relation to our lives and activities is something we should 'remember and confess' (Orlin 2005:38).

The biblical context stated above is extremely important for the proper understanding of the examined text because, as Cook (2019) underlines:

[A] fundamental concept in the formulation of a suitable theory of translation is the constitutive character of a text. When a translated text is considered with respect to the historical enterprise which gave rise to it, namely its originating Sitz im Leben, it becomes readily apparent that the verbal character of the document will to some extent reflect the socio-linguistic practices proper to the larger cultural undertaking of which it was a part. (p. 2)

\section{Planning the future and God's will in the biblical and patristic theology}

James does not affirm that man cannot decide on anything, he does not deny human freedom, he only reminds us of the fact that man should decide in cooperation with God's grace and in agreement with God's will. This idea is confirmed by Oikoumeniou (2006) who says that James:

$[D]$ oes not deny the free will, he just points to the fact, that not everything is its power. Free will needs grace from above. Indeed, it is possible to strive, and to travel, and to trade and to do everything (necessary) for life, yet to ascribe it not to your effort, but to God's philanthropy. (p. 471)

Thus, James does not reject business and trade as such. His reservations are focussed on man's life far from God and on the situation when someone sees the aim of his entire life in the efforts to achieve working results, progress, success and profit. His warning is addressed to the people whose 'plans are focused exclusively on building happiness in this life and age' (Agourídē 1956:76). James describes the results of such a behaviour in the following chapter (Ja 5:1-6). Man should be active, determined, full of initiative, hard-working and should do everything needed to take care of his affairs and livelihood. Man should not expect that God will do everything for him. However, he should comprehend the fact that his activities and decisions bring a real benefit only if they are in line with God's commandments, with a healthy spiritual life and a moral purity (Župina 2019:63). An example of the right comprehension of the cooperation between God and man is the words of the prophet Jeremiah: 'O Lord, I know the way of man is not in himself; it is not in man who walks to direct his own steps' (Jr 10:23). Paul also reminds us that all good things we have or what we achieve would be impossible to do without the multitude of God's gifts we received: 'And what do you have that you did not receive? Now if you did indeed receive it, why do you boast as if you had not received it?' (1 Cor 4:7).
The plans and the activities developed by man without considering God's will and God's commandments, the most important being the commandment of love among them, will end badly, even if, seen from outside, they were successfully finalised:

Can we plan, can we intervene and can we control outcomes and directions? Starting with the last question, the answer seems to be that we can merely participate, but not control. (Gous 2021:4)

From the presented words results the fact that the successful businesses of the traders, without the right moral and spiritual principles inspired by God, end in injustice, evil and sin, that is without a real success and benefit for all.

\section{The spiritual and moral aspect of planning the future}

In this verse, the words of apostle James give evidence that some of the addressees of the letter had not yet gained a number of very important Christian virtues without which God and His grace cannot co-act in their lives. For, the work of God's grace 'occurs in man's soul, assuming a great patience, wisdom and the mysterious functioning of the reason' (Župina 2017:78-79).

This action is perfect, active and pleasing to God only when man's life is fruitful (4) and in agreement with God's will. The example of Joseph, the son of forefather Jacob, proved to be universally valid only after many difficulties and suffering, ... when he proved to be in every way a strong and experienced servant of God. Things happened similarly with David, too. James had these examples in mind when he criticises those to whom are assigned his words: Now listen, you who say, 'Today or tomorrow we will go to such and such a city'.... Such people did not renounce yet to the love for the world. They do not focus only on God, do not think only of Him, do not search only Him ... Their plans are unsteady because they are captivated only by the material profit and they do not know what will happen the next day with them and their plans. (Mrđa 2004:73)

We live in a time when planning has become a scientific domain and usually almost everything is being planned, sometimes even what should not be planned. Nevertheless, in our planning we should not forget God, the other people (Hangoni 2018:12-16) and our soul. Our planning can be useful, good and blessed only if as a consequence of it other people do not have to suffer, if it does not deprive us of our spiritual life and salvation and if it does not imply the disregard of God and blasphemy. We should live and plan in such a way that for our selfish planning of an easy or wealthy future should not have to pay with their lives the unborn or non-conceived children. Our plans should not mean enmity with God and should not exclude Him from our community (5) and society. Finally, they should not lead to the death of our soul or the souls of other people. The reasonable remembrance of the above-mentioned factors is not meant to destroy our plans, but to add to our planning humbleness, reasonableness, dedication, patience, faith, hope and love (6). If in our planning we remember God and His will, the other people, our soul and salvation and also the eternity, this will 
protect us from mistakes, sins, disappointments and a loss of bliss in eternity. Precisely the same aim had also the words of Jesus Christ in the parable of the rich fool (see Lk 12:16-21).

\section{Discussion}

We have discovered and formulated two new translations of biblical expressions that are not yet used in current ecumenical translations of the Bible. These translations have real potential to improve and refine the existing ecumenical translation. The strength of our research is the interpretation of source biblical texts based on Greek manuscripts. In the future, it is possible to continue the research by taking into account the oldest Syrian and Coptic interpretations of the original text. What is more, it is possible to draw further exegetical conclusions for the area of spirituality and ethics in the future.

\section{Conclusion}

\section{Findings}

On the basis of this exegetical analysis, we concluded that hapax legomenon 'A $\gamma \varepsilon$ võv must be translated as 'hear now' so that the term remains an urgent call for immediate attention, and at the same time points to eschatological thinking that does not allow any postponement of positive activities and changes to the future. Although the verb 'A $\gamma \varepsilon$ is an imperative from the verb $\alpha \gamma \omega$, the basic meaning of which is: 'to walk' or 'to go', it is more appropriate to use 'hear' instead of the imperative 'come' because these are words that were not uttered in a personal encounter but in the letter. It is an indirect and mediated contact with the listeners, who are not encouraged to go somewhere, but to hear and perceive an urgent call. The second conclusion is the finding that the term $\pi \circ \eta \dot{\sigma o \mu} \varepsilon v$, which in most translations, including the latest text of the Slovak Ecumenical Bible, translates as 'remain' (stay), is more appropriate to translate as 'work'. This last expression is a more authentic translation of the original biblical text and has an important influence on the active interpretation of the text in relation to the presence and practice.

We, therefore, state that the linguistic and exegetical analysis made it possible to find a more accurate meaning of the researched text, which can really contribute to the improvement of further review and publication of the translation of the Bible not only into Slovak but also into other languages. What is more, this way it brings a new light into the researched topic, that is, the strategy of planning for the future according to the apostle James.

\section{Notes}

1. We find the opposite of such action in the holy mystery of marriage, where two young people, fulfilling God's will, enter into complete physical and mental unity (Šak, Kochan \& Pilko 2019a).

2. Gaius Plinius Caecilius Secundus - Pliny the Younger between 111 and 113 was the governor of Bithynia province. The mentioned letter contains a report of the court trials of Christians (Gaius Plinius:238-242).
3. See the ecumenical, Catholic, Protestant, Rohaček's and Botek's translations, viewed 04 September 2020, from https://biblia.sk/citanie/seb/jk/4.

4. The Church exhorts us to be active, to move: that is, it encourages us to pray, to repent, to wrestle with ourselves, to live liturgically, to walk and to go to God. And we still fall. Behold, there is something great about this. And that is the movement of the soul towards its Creator as a therapeutic cut in the treatment of man (see Šak 2018:43-44).

5. People, often under the influence of secularisation, are influenced by different habits as well as the environment and do not understand their inappropriate actions and behaviour (see Šak 2019:43-44).

6. This is the effort and struggle to return the mind back to the heart - in accordance with patristic terminology it is called the work of the mind, which includes sobriety, attention and prayer of the mind (see Šak 2017:27-28).

\section{Acknowledgements}

This article is one of the results of the implementation of the scientific research project 'The behaviour of the young consumers during the Feasts (in the Czech Republic and the Slovak Republic)' of the Grant Agency of the University of Prešov (GAPU no. 36/2020).

\section{Competing interests}

The authors declare that they have no financial or personal relationships that may have inappropriately influenced them in writing this article.

\section{Authors' contributions}

All authors contributed equally to this work.

\section{Ethical considerations}

This article followed all ethical standards for research without direct contact with human or animal subjects.

\section{Funding information}

This work was supported by the Grant Agency of the University of Prešov [GAPU no. 36/2020].

\section{Data availability}

Data sharing is not applicable to this article as no new data were created or analysed in this study.

\section{Disclaimer}

The views and opinions expressed in this article are those of the authors and do not necessarily reflect the official policy or position of any affiliated agency of the authors.

\section{References}

Agourídē, S.K., 1956, Upómnēma eis tến epistolến toũ Agíou lakốvou [Commentary on the epistle of Saint James], National and Kapodistrian University of Athens, Athens. 
Aland, K., Mink, G., Strutwolf, H. \& Wachtel, K., 2014, Novum Testamentum Greacum, editio Critica maior, IV: Catholic letters, Part 1: Text, Deutsche Bibelgesellschaft, Stuttgart.

Aland, K., Karavidopoulos, J., Martini, C.M., Metzger, B.M. \& Strutwolf, H. (eds.), 2018 Novum Testamentum Graece with dictionary, 28th rev. edn., Deutsche Bibelgesellschaft, Stuttgart.

Bándy, J., Peres, I., Škoviera, D., Trstenský, F., Vilhan, P., Ábel, F. et al., 2015, Slovenský ekumenický preklad s deuterokánonickými knihami [Slovak Ecumenical translation with Deuterocanonical Books], Slovenská biblická spoločnost', Banská Bystrica.

Bibliia, 1993, Knigi SViashhchennogo Pisaniia Vetkhogo $i$ Novogo Zaveta na tserkovnoslavianskom iazyke [Books of the holy scriptures of the Old and New Testaments in church Slavonic], Rossiilskoe bible šskoe obshchestvo, Moscow.

Botek, A., 2012, 'Botekov preklad - Jakubov list 4', in Biblia.sk, viewed 04 September 2020 from https://biblia.sk/citanie/bot/jk/4.

Cap, A., 2018, 'Povolanie Abrama (1MJŽ 12, 1-9), (biblicko-exegetický komentár na dvanástu kapitolu knihy Genezis)' [The Vocation of Abram (Gen 12:1-9), (a biblicalexegetical commentary on the twelfth chapter of the book of Genesis)], Historia Ecclesiastica: časopis pre dejiny cirkví a náboženstiev v Strednej Európe 9(1), 191-207.

Cap, A., 2019, 'Abrahám v Egypte: (biblicko - exegetický komentár na 1MJŽ 12, 10-20)' [Abraham in the Egypt: (Biblical - Exegetical commentary on Gen 12:10-20)], Historia Ecclesiastica: časopis pre dejiny cirkví a náboženstiev v Strednej Európe 10(2), 222-232.

Cook, J., 2019, 'Contextuality and the Septuagint', HTS Teologiese Studies/Theological Studies 75(3), a5029. https://doi.org/10.4102/hts.v75i3.5029

Dvoretskiĭ, I.K.H.L 1958, Drevnegrechesko-russkiĭ slovar' [Ancient Greek-Russian dictionary], Natsional'noe izdatel'stvo inostrannykh i natsional'nykh slovarel̆, Moscow.

Gous, I.G.P., 2021, 'Rethinking the past to manage the future: Participating in complex contexts informed by biblical perspectives', HTS Teologiese Studies/Theological contexts informed by biblical perspectives', HTS Teologiese Stud
Studies 77(3), a6316. https://doi.org/10.4102/hts.v77i3.6316

Gryglewicz, F., 1959, Pismo Święte Nowego Testamentu w 12 tomach. Listy Katolickie. Wstęp, przekład z oryginału, komentarz [The holy scriptures of the New Testament in 12 volumes: Catholic letters: Introduction, translation from the original, commentary], Pallottinum, Poznań.

Hangoni, T., 2016, 'Profesionálna práca s rodinou' [Professional work with the family], in J. Husár (ed.), 65 rokov teologickej činnosti Pravoslávnej bohosloveckej fakulty: (jubilejný zborník), pp. 160-163, Prešovská univerzita v Prešove, Pravoslávna bohoslovecká fakulta, Prešov.

Hangoni, T., 2018, 'Social theology and its role in social work', Sociálna a duchovna revue: vedecký recenzovaný ćasopis 9(2), 12-16.

Hanobik, F., 2020, Sociálna práca s marginalizovanými skupinami [Social work with marginalized groups], Wydawnictwo Katedry Filozofii Akademii Ekonomiczno Humanistycznej w Warszawie, Warsaw.

Hanobik, F. \& Jurašek, M., 2019, Organizácia sociálnej starostlivosti, Wydawnictwo Katedry Filozofii Akademii Ekonomiczno - Humanistycznej w Warszawie, Varšava.

Hoppe, R., 2001, List Jakubův [The Letter of James], Karmelitánské nakladatelství, Kostelní Vydř́.

Taroshevskii, G., 1901, Sobornoe Poslanie sv Apostola lakova [General letter of Saint Apostle James], s.n., Kiev.

Ivanov, A., 1893, Rukovodstvo k izi asnitel'nomu chtenii u knig Novago Zaveta, Obozrenie poslanii apostol'skikh" $i$ Apokalipsisa [Guide to Explanatory Reading of the Books of the New Testament, Review of the Epistles of the Apostles and the Apocalypse], s.n., Saint Petersburg.

Kibal'chich', I., 2004, Opyt obozreniia i ob’iasneniia sobornogo poslaniia sv ap lakova [The experience of reviewing and explaining the general letter of St. Ap. James] Perervinskaia dukhovnaia seminariia, Moscow.
McCracken, A., 2002, The book of Enoch, Scriptural-truth.com, viewed 05 September 2020, from http://scriptural-truth.com/images/BookOfEnoch.pdf.

Mrđa, N., 2004, Tumačenje sabornih poslanica (Jakovljeve, Prve i Druge Petrove) Svetoga Pisma Novoga Zaveta [Interpretation of the Epistles (James, First and Second Peter) of the holy scriptures of the New Testament], Dabar i Bogoslovija Svetog Petra Dabrobosanskog, Srbinje.

Nikodếmou, A., 1986, Ermēneía eis tás epta Katholikás' Epistolás Tw̃n 'Agíōn' Apostólōn' lakốvou, Pétrou', Iōánnou kai' loúda. [Interpretation of the seven general epistles of the holy Apostles James, Peter, John and Jude], Ekdóseis Orthódoxos kupsélē, Thessaloniki.

Oikoumeniou, T., 2006, 'Úpomnếmata eis tás katholikás' Epistolás. lakovou Apostolou è katholikế episolế. Tomos 119', [Commentaries on general letters: General letter of the Apostle James. Volume 119], in G.D. Dragas (ed.), Ellēnike Patrologia (Patrologia Graeca), pp. 456-509, Kéntron Paterikốn Ekdóseōn (KE.P.E.), Athens.

Orlin, N., 2005, Sobornyia poslaniia apostola lakova, pervoe i vtroe ap. Petra i ap. Iudy [General letters of the Apostle James, First and Second of the Ap. Peter and of Ap. Jude], Perervinskaia dukhovnaia seminariia, Moscow.

Plinius, G., 1942, Dopisy, transl. R. Kuthan, Jan Laichter, Praha.

Ráptē, G.A., 1992, Megálo lexēkó rēmátōn. Tomos 1-2 [Large dictionary of verbs. Volume 1-2], George T. Konteos, Thessaloniki.

Ráptē, G.A., 1993, Lexiko orthographiko-ermēneutiko tēs arkhaias ellēnikēs glōssas [Orthographical and hermeneutical dictionary of the ancient Greek language] George T. Konteos, Thessaloniki.

Roháček, J., 2017, 'Roháčkov preklad - Epištola svätého Jakoba 4', in Biblia.sk, viewed 04 September 2020, from https://biblia.sk/citanie/roh/jk/4.

Šak, Š., 2017, 'Niptická metóda terapie v duchu pravoslávnej tradície' [Niptic method of therapy in the spirit of the Orthodox tradition], in J. Husár (ed.) Vybrane aspekty duchovného života z pohl'adu učenia Pravoslávnej Cirkvi: zborník aspekty duchovného zivota z pohladu ucenia Pravoslavnej Cirkvi: zbornik
vedeckých príspevkov, pp. 27-28, Prešovská univerzita v Prešove, Pravoslávna vedeckých príspevkov, pp. 27-28, Prešovská univerzita v Prešove, Pravoslávna
bohoslovecká fakulta, Prešov.

Šak, Š., 2018, 'Pokánie v procese terapie človeka' [Repentance in the process of human therapy], in Vybrané aspekty fenoménu pokánia, pp. 43-44, Centrum spirituality Východ - Západ Michala Lacka, Košice.

Šak, Š., 2019, 'Svadobná hostina v kontexte svätej tajiny manželstva' [A wedding reception in the Context of the Holy Mystery of Marriage], in J. Husár (ed.), Biblia a wspólczesnosc: teologiczne, kanoniczne, socjalne i spoleczne przeslanie Biblii dla a wspólczesnosc: teologiczne, kanoniczne, socjalne i spoleczne przeslanie Biblii dla
wspólczesnosci, pp. 42-49, Diecezjalny osrodek kultury prawoslawnej ELPIS w wspólczesnosci, pp.

Šak, Š., Kochan, P. \& Pilko, J., 2019a, Christian family in modern society (Theological Sociological - Biblical - Pedagogical view), Department of Central and Eastern European History of University of Bialystok, Bialystok.

Šak, Š., Kochan, P. \& Pilko, J., 2019b, Mystérium manželstva [The mystery of marriage], Diecezjalny osrodek kultury prawoslawnej ELPIS w Gorlicach, Gorlice.

Trempélas, P.N., 1996, 'Upómnēma eis tás' Epistolás tñs Kainñs Diathếkēs. t. 3 [Commentary on the New Testament epistles. vol. 3], Adelfotis Theologon 'O Sotir', Athens.

Župina, M., 2017, 'Mystický realizmus gnozeológie Symeona Nového Teológa' [Mystical realism of Gnoseology of Symeon the New Theologian], Konštantínove listy 10(1), 73-82. https://doi.org/10.17846/CL.2017.10.1.73-82

Župina, M., 2019, 'Historicko-teologický vývoj isychazmu v pravoslávnej tradícii s akcentom na obdobie 9-11, storočia' [Historical-theological development of Hesychasm in the orthodox tradition with an emphasis on the period of the 9th 11th century], Historia Ecclesiastica: časopis pre dejiny cirkví a náboženstiev v Strednej Európe 10(2), 50-64. 